\title{
COST BENEFIT ANALYSIS FOR SIGNAL FREE TRAFFIC AT INTERSECTION: A CASE STUDY
}

\author{
Sanjay Shivaji More ${ }^{1}$, Vishal D. Sabale ${ }^{2}$ \\ ${ }^{1,2}$ Assistant Professor, Civil Engineering Department, BVCOE Lavale Pune, Maharashtra, India
}

\begin{abstract}
Signal free junction is reducing fuel consumption, accidents and travel time. In that paper discuss the cost-benefit ratio of signal free junction at Vishrambagh Intersection, Sangli, Maharashtra, India. Here we studied the various cost as well as benefits included in signal free junction. The Results indicate that the Signal free junction may be economically viable. A benefit/cost ratio of 1.82 is generated in year 2027.
\end{abstract}

Keywords: Vehicle Operating Cost, Accident Cost, Travel time saving cost and Cost Benefit Ratio etc...

\section{INTRODUCTION}

There are a number of variations of Cost-Benefit analysis method, but a simple procedure is to discount all costs and benefits to their present worth and calculate the ratio of the benefits to costs. Here to evaluate the cost as well as benefits available from the implementation of a signal free junction and to demonstrate the Cost and user benefits of Juntion improvement analysis. This evaluation was intended as a guide for planning and decision-making. Negative flows are considered as costs whereas positive flows as benefits. Thus the saving in the transport cost is considered as benefits. If the $\mathrm{B} / \mathrm{C}$ ratio is more than 1.52 , the project is worth undertaking.

The objectives of this study were to evaluate the potential benefits available from the implementation of a Signal free junction at Vishrambagh intersection and to calculate the user Benefits of Junction improvement. This evaluation was intended as a guide for planning and decision-making.here.

\section{IMPROVEMENTS FOR VISHRAMBAGH JUNCTION}

According to traffic analysis; in Vishrambagh junction the heavy traffic along the Sangli-Miraj and Miraj-Sangli road. Kupwad to Sangli is also having medium traffic. If the flyover will provide at Vishrambagh Junction along the Sangli-Miraj road and underpass will provide along KupwadSangli, then the large amount of traffic lifted and moves on the grade separator.

If large amount of traffic will moves on the grade separator, then traffic movement at Vishrambagh junction is signal free as well as the traffic congestion problem will be solved. This flyover covered 1 major junction and 3 minor junctions. Vishrambagh is major as well as important junction. Start point location of flyover is in one side Walchand College's main gate and another side is Vishrambagh post office. End point location of flyover is in one side of road Deep enterprises and another side is Jalbhawan.

Table -1: Salient Features of Underpass

\begin{tabular}{|l|l|}
\hline Type of Underpass & Open Cut \\
\hline Length of Underpass & $400 \mathrm{~m}$ \\
\hline Number of Lane & $\begin{array}{l}\text { Single lane } \\
\text { unidirectional }\end{array}$ \\
\hline Carriageway Width & $5.5 \mathrm{~m}$ \\
\hline Vertical Clearance & $4.5 \mathrm{~m}$ \\
\hline Gradient & $5 \%(1$ in 20) \\
\hline $\begin{array}{l}\text { Length of Approach Ramp } \\
\text { towards Kupwad as well as } \\
\text { sangli }\end{array}$ & $150 \mathrm{~m}$ \\
\hline Width of drainage line & $0.5 \mathrm{~m}$ \\
\hline Radius of curvature & $64 \mathrm{~m}$ \\
\hline Speed limit & $80 \mathrm{kmph}$ \\
\hline
\end{tabular}

Table -2: Salient Features of Flyover

\begin{tabular}{|l|l|}
\hline Total Length of Flyover & $1400 \mathrm{~m}$ \\
\hline Number of Lane & 4 lane- One way \\
\hline Vertical Clearance & $5.5 \mathrm{~m}$ \\
\hline Carriageway Width & $7.5 \mathrm{~m}$ \\
\hline Total road width & $18.5 \mathrm{~m}$ \\
\hline Ruling Gradient & $5 \%(1$ in 20) \\
\hline $\begin{array}{l}\text { Length of flyover (without } \\
\text { Abutment) }\end{array}$ & $1000 \mathrm{~m}$ \\
\hline Length of Abutment & $\begin{array}{l}400 \mathrm{~m} \text { (200m at } \\
\text { entry and } 200 \mathrm{~m} \text { at } \\
\text { exit) }\end{array}$ \\
\hline Width of shoulder & $0.5 \mathrm{~m}$ \\
\hline Width of Parapet wall & $0.25 \mathrm{~m}$ \\
\hline
\end{tabular}

\section{COST FOR SIGNAL FREE JUNCTION}

Cost for signal free junction includes Construction cost, Maintenance cost and Road user cost. According to Survey the approximate cost per square meter of Flyover and underpass in 2015 is $59000 \mathrm{Rs} / \mathrm{m}^{2}$ and $35000 \mathrm{Rs} / \mathrm{m} 2$ respectively. 
Cost for signal free Vishrambagh junction is

\begin{tabular}{|l|l|l|}
\hline Name & Cost X Area & Cost \\
\hline flyover & $59000 \times 25900$ & $152.81 \mathrm{cr}$ \\
\hline Underpass & $35000 \times 2200$ & $7.70 \mathrm{cr}$ \\
\hline $\begin{array}{l}\text { signal free } \\
\text { Vishrambagh } \\
\text { Junction }\end{array}$ & & $\begin{array}{l}\mathbf{1 6 0 . 5 1 \mathrm { cr }} \\
\text { (Approximately) }\end{array}$ \\
\hline
\end{tabular}

According to "Highway Capacity Manual 2000", to calculate yearly traffic volume in terms of PCU/day with $9 \%$ growth rate from year 2014 to 2040 and also calculate V/C Ratio.

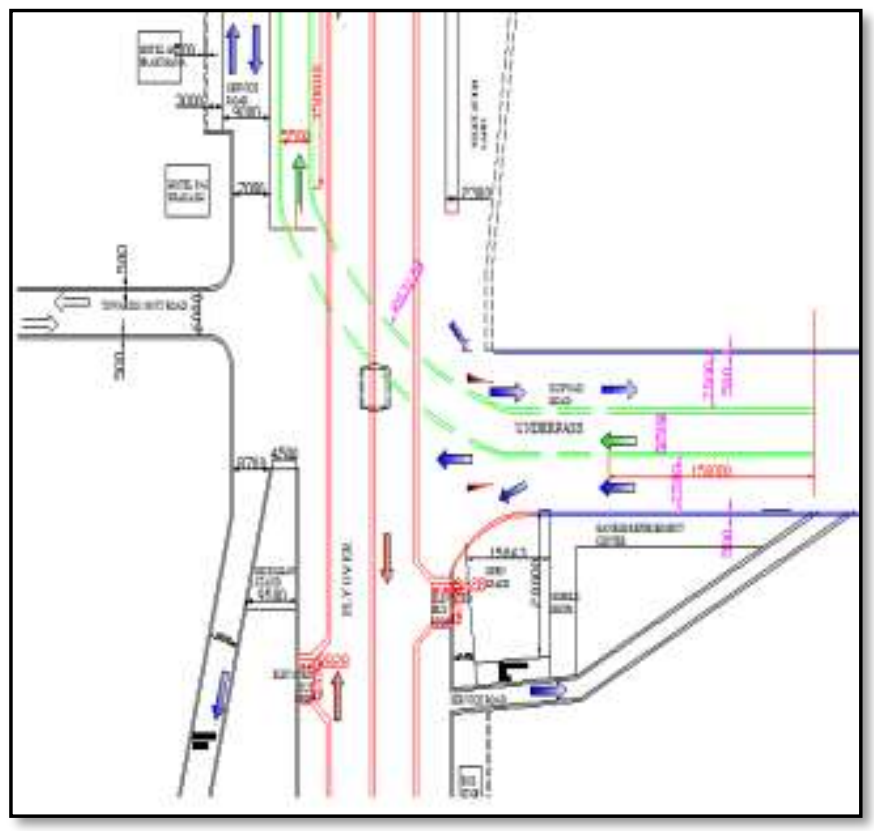

Fig -1: Improved Vishrambagh Junction

\section{BENEFITS FROM SIGNAL FREE JUNCTION}

Benefits from Signal free junction can be classified as Road Users Benefits and Social Benefits. Road user benefits include Vehicles operating cost saving, Value of saving in accident cost, saving in maintenance cost, Value of travel time saving. Social benefits include Improvements in Health and education, Improvements in industry, agriculture, mining and trade, Improvements in law and order, administration and defense and Improvements in environmental standards. In benefit calculation; $1^{\text {st }}$ determine the Vehicle Operating Cost (VOC), according to IRC SP: 30-2009.

Benefit from signal free junction includes Vehicle operating cost saving, Value of travel time saving, Saving in maintenance cost and Value of saving in Accident cost. In benefit calculation, first determine the Vehicle Operating Cost (VOC). For determining the VOC, following road specifications values are required: Roughness of road: 2000$3000 \mathrm{~mm} / \mathrm{Km}$ (Bituminous concrete), Terrain: Plain, RF (Rise and Fall) per $\mathrm{Km}=0-15$, Low curvature $=$ less than 50, Design Service value in PCU/day, Underpass (intermediate lane): $6000 \mathrm{PCU} /$ day with earthen shoulder. Flyover (Four lanes): 40000 PCU/day with paved shoulder. Here to find out traffic per day at existing junction as well as traffic distribution in signal free junction. According to RTO office in Sangli, the night traffic is $30 \%$ of the morning traffic.

\subsection{Vehivle Operating Cost Saving}

CASE I:Traffic Volume on existing road junction; According to "Highway Capacity Manual 2000", to calculate yearly traffic volume in terms of PCU/day with $9 \%$ growth rate from year 2014 to 2039 and also calculate Volume/Capacity Ratio. Formula for v/c ratio for entry lane of Signalized Intersection; V/C Ratio $=\left(\mathbf{V}_{\mathbf{i}} \times \mathbf{C}\right) /\left(\mathbf{S}_{\mathbf{i}} \times \mathbf{g}_{\mathbf{i}}\right) \mathrm{V}_{\mathrm{i}}$ $=$ Actual Flow rate of lane, $S_{i}=$ Saturation Flow Rate of Lane, $g_{i}=$ Effective Green Time, $\mathrm{C}=$ Cycle Length $\mathbf{s}_{\mathbf{0}}=$ base saturation flow rate, $\mathrm{N}=$ number of lanes in lane group, $\mathrm{f}_{\mathrm{HV}}$ $=$ factor for heavy vehicles in traffic stream, $\mathrm{f}_{\mathrm{bb}}=$ factor for blocking effect of local buses that stop in intersection, $\mathrm{f}_{\mathrm{LT}}=$ factor for left turn in lane group.

v/c ratio for Miraj road: $s_{i}=s_{\mathbf{o}} \mathbf{N} \mathbf{f}_{\mathrm{HV}} \mathbf{f}_{\mathrm{bb}} \mathbf{f}_{\mathrm{LT}}$ $=1900 \times 2 \times 0.95 \times 0.94 \times 0.77=2613$.

Table -3: Traffic Volume data (2014)

\begin{tabular}{|l|l|l|l|l|}
\hline Type of Vehicle & $\begin{array}{l}\text { No. of Vehicle per } \\
\text { day on ExistJunct }\end{array}$ & $\begin{array}{l}\text { PCU/DAY at } \\
\text { Existing Junction } \\
\text { ( Case I })\end{array}$ & $\begin{array}{l}\text { PCU per DAY at Existing } \\
\text { Junction after Junction is } \\
\text { Signal free } \\
\text { Case II }\end{array}$ & $\begin{array}{l}\text { PCU/DAY of Underpass and } \\
\text { flyover after Junction is signal } \\
\text { Free } \\
\text { ( Case III ) }\end{array}$ \\
\hline Motor cycle & 49585 & 37189 & 15256 & 21933 \\
\hline Car/jeep & 12906 & 12906 & 4628 & 8278 \\
\hline Auto Rickshaw & 7921 & 15842 & 3375 & 12467 \\
\hline LCV & 1567 & 2194 & 577 & 1617 \\
\hline Truck/Bus/ Tempo & 2577 & 5669 & 941 & 4728 \\
\hline Tractor & 85 & 354 & 182 & 172 \\
\hline MAV & 259 & 1035 & 161 & 874 \\
\hline
\end{tabular}


V/C ratio Calculation: $\mathrm{V} / \mathrm{C}=\left(\mathrm{v}_{\mathrm{i}} \times \mathrm{C}\right) /\left(\mathrm{s}_{\mathrm{i}} \times \mathrm{g}_{\mathrm{i}}\right)=(2284 \mathrm{x}$ $105) /(2613 \times 35)=2.62$

V/C ratio For Vishrambagh Junction $=(2.62+2.67+$ $2.85+2.5+0.57+0.35) / 6=1.92=\mathbf{1}$ from year 2014 to 2039, the Volume -capacity ratio is $\mathbf{1}$ (Note: $>1$ Value is also taken as 1),for Existing Signalized Road Junction.

CASE II : Traffic Volume on the exiting junction after providing Grade Separated intersection. According to the paper "Comparison of capacity between roundabout design and signalized junction design" in Swiss transport Research Conference in March 2001, The Formula for Capacity of junction:(Roundabout),
$\mathbf{Q}_{\mathrm{fcr}}=6 \times 1500 /\{1 / 1.4+[0.6 \times(0.865)+0.24] \times 8 / 9\}=\mathbf{6 4 8 0}$ PCU/hr

$\mathrm{Q}_{\mathrm{fcr}}=$ Full Capacity of Roundabout Junction, $\mathrm{F}$ and $\mathrm{f}=$ Coefficients (For the Roundabout design, $F=1500 \& \mathrm{f}=$ $8 / 9), \mathrm{K}=$ Parameter (2 lane in the entry , $\mathrm{k}=1.4-1.6$ ), $\beta=$ Parameter taking account of multilane $\mathrm{s}$ in the circulating carriageway ( 2 lanes in the circulating carriageway, $\beta=0.6$ $-0.8), \alpha=$ Parameter reflecting the degree of vehicles in the entry disturbed by the Vehicles existing at the same branch, $\mathrm{R}_{\mathrm{h}}=$ the ratio of going ahead of roundabout, $\mathrm{R}_{\mathrm{L}}=$ the ratio of turning left of roundabout. The construction work required approximately 5 years. Volume of traffic in $2014=$ $2444 \mathrm{PCU} / \mathrm{hr}$. V/C in $2019=3760 / 6480=0.58$, year 2026 onwardsv/c=1

$Q_{\text {fcr }}=6 F /\left\{1 / K+\left[\beta \times\left(R_{h}+2 R_{L}\right)+\alpha\right] \times f\right\}$

Table -4.1: Lanes and there details

\begin{tabular}{|l|l|l|l|l|l|l|l|l|l|l|}
\hline Sr. No. & Lane & $\mathrm{s}_{\mathrm{o}}$ & $\mathrm{N}$ & $\% \mathrm{HV}$ & $\mathrm{f}_{\mathrm{HV}}$ & $\mathrm{N}_{\mathrm{B}}$ & $\mathrm{f}_{\mathrm{bb}}$ & $\mathrm{P}_{\mathrm{LT}}$ & $\mathrm{f}_{\mathrm{LT}}$ & $\mathrm{s}_{\mathrm{i}}$ \\
\hline 1 & Traffic coming from Sangli Road & 1900 & 2 & 4.9 & 0.95 & 30 & 0.94 & 6 & 0.77 & 2613 \\
\hline 2 & Traffic coming from Miraj Road & 1900 & 2 & 5.1 & 0.95 & 21 & 0.95 & 6 & 0.77 & 2641 \\
\hline 3 & Traffic coming from Kupwad Road & 1900 & 2 & 2.2 & 0.98 & 7 & 0.986 & 6 & 0.77 & 2827 \\
\hline 4 & Traffic coming from Vishrambagh Road & 1900 & 1 & 1.1 & 0.99 & 0 & 1 & 6 & 0.77 & 1449 \\
\hline 5 & Traffic coming from Dandekar mall Road & 1900 & 1 & 1 & 0.99 & 0 & 1 & 6 & 0.77 & 1449 \\
\hline 6 & Traffic coming from Sai Prathna hotel Road & 1900 & 1 & 0.68 & 0.99 & 28 & 0.94 & 6 & 0.77 & 1361 \\
\hline
\end{tabular}

Table-5.1: Lanes and there $\mathrm{v} / \mathrm{c}$ ratios

\begin{tabular}{|l|l|l|l|l|l|l|l|l|l|}
\hline $\begin{array}{l}\text { Sr. } \\
\text { No }\end{array}$ & Lane & $\begin{array}{l}\mathrm{V}_{\mathrm{i}} \\
\mathrm{Veh} / \mathrm{hr}\end{array}$ & $\begin{array}{l}\mathrm{S}_{\mathrm{i}} \\
\mathrm{Veh} / \mathrm{hr}\end{array}$ & $\begin{array}{l}\text { Green } \\
\text { Time } \\
(\mathrm{sec})\end{array}$ & $\begin{array}{l}\text { Clearance } \\
\text { time } \\
(\mathrm{sec})\end{array}$ & $\mathrm{g}_{\mathrm{i}} \mathrm{sec}$ & $\begin{array}{l}\text { Red } \\
\text { Time } \\
\mathrm{sec}\end{array}$ & $\begin{array}{l}\text { C sec } \\
\text { V/C } \\
\text { Ratio }\end{array}$ \\
\hline 1 & Traffic from Sangli Road & 2284 & 2613 & 30 & 5 & 35 & 70 & 105 & 2.62 \\
\hline 2 & Traffic from Miraj Road & 2449 & 2641 & 30 & 5 & 35 & 75 & 110 & 2.67 \\
\hline 3 & Traffic from Kupwad & 1469 & 2827 & 16 & 4 & 20 & 90 & 110 & 2.85 \\
\hline 4 & Traffic from 100ft Road & 638 & 1449 & 10 & 5 & 15 & 70 & 85 & 2.5 \\
\hline 5 & Traffic from Dandekar mall & 266 & 1449 & 30 & 5 & 35 & 75 & 110 & 0.57 \\
\hline 6 & Traffic from Sai Prathna Hotel & 160 & 1361 & 30 & 5 & 35 & 70 & 105 & 0.35 \\
\hline
\end{tabular}

\begin{tabular}{|l|l|}
\hline Type of Junction & Existing Junction after signal free \\
\hline $\mathrm{L}_{\mathrm{ba}}$ & $17 \mathrm{~m}$ \\
\hline$\alpha$ & 0.24 \\
\hline $\mathrm{R}_{\mathrm{h}}+2 \mathrm{R}_{\mathrm{L}}$ & 0.865 \\
\hline
\end{tabular}

CASE III: V/C ratio for Underpass \& Flyover after junction is Signal free.

Table-6: Volume Capacity ratio for flyover and Underpass

\begin{tabular}{|l|l|l|l|l|l|l|}
\hline \multirow{2}{*}{ Year } & \multicolumn{4}{|l|}{ Underpass } & \multicolumn{2}{l|}{ Flyover } \\
\cline { 2 - 7 } & $\mathrm{V}$ & $\mathrm{C}$ & $\mathrm{V} / \mathrm{C}$ & $\mathrm{V}$ & $\mathrm{C}$ & V/C \\
\hline 2014 & 770 & & & 3709 & & \\
\hline 2019 & 1184 & 2000 & 0.59 & 5706 & 6000 & 0.95 \\
\hline 2020 & 1291 & 2000 & 0.62 & 6220 & 6000 & 1 \\
\hline 2025 & 1986 & 2000 & 0.99 & 9570 & 6000 & 1 \\
\hline 2026 & 2165 & 2000 & 1 & 10432 & 6000 & 1 \\
\hline 2030 & 3057 & 2000 & 1 & 14725 & 6000 & 1 \\
\hline
\end{tabular}

The v/c ratio is obtained " 1 " immediately, but due to continuous movement of vehicles on flyover and underpass; no traffic congestion problems are occurred. As traffic volume on a road increases, the vehicles have to overtake, cross, accelerate and decelerate. These maneuvers result in drop in speeds and increase in fuel consumption along with wear and tear of vehicles. The effect of congestion on VOC can be considered separately for the distance-related and time-related components.

CASE I: Traffic Volume on existing road junction Sample Calculation: Two Wheeler Distance Related Congestion Factor $\mathbf{C F}_{\mathbf{D}}=\{0.917+0.112 \mathrm{x}$ $(\mathrm{V} / \mathrm{C})\} \times 0.8=\{0.917+0.112 \times(1)\} \times 0.8=0.82=\mathbf{1}$

Time Related Congestion Factor $\mathbf{C F}_{\mathbf{T}}=\{0.804+0.865 \mathrm{x}$ $(\mathrm{V} / \mathrm{C})\} \times 0.8=\{0.804+0.865 \times(1)\} \times 0.8=\mathbf{1 . 3 3}$ 
Table-7.1: Distance \& Time Related Corrected Congestion Factor (Case I)

\begin{tabular}{|l|l|l|l|l|l|l|l|l|}
\hline Year & \multicolumn{3}{|l|}{$\begin{array}{l}\text { Motor } \\
\text { Cycle }\end{array}$} & \multicolumn{2}{l|}{ Jeep/car } & \multicolumn{2}{l|}{$\begin{array}{l}\text { Autol } \\
\text { 6 seater }\end{array}$} & \multicolumn{2}{l|}{$\begin{array}{l}\text { LCV } \\
\text { (pick up) }\end{array}$} \\
\cline { 2 - 10 } & $C F_{D}$ & $C F_{T}$ & $C F_{D}$ & $C F_{T}$ & $C F_{D}$ & $C F_{T}$ & $C F_{D}$ & $C F_{T}$ \\
\hline 2014 & 1 & 1.33 & 1 & 1.26 & 1.52 & 1.2 & 1.52 & 1.2 \\
\hline 2015 & 1 & 1.33 & 1 & 1.26 & 1.52 & 1.2 & 1.52 & 1.2 \\
\hline 2027 & 1 & 1.33 & 1 & 1.26 & 1.52 & 1.2 & 1.52 & 1.2 \\
\hline
\end{tabular}

Table-7.2: Distance \& Time Related Corrected Congestion Factor (Case I)

\begin{tabular}{|l|l|l|l|l|l|l|l|l|}
\hline Year & \multicolumn{2}{|l|}{$\begin{array}{l}\text { Truck\Bus } \\
\text { Tempo }\end{array}$} & \multicolumn{2}{l|}{ Tractor } & \multicolumn{2}{l|}{$\begin{array}{l}\text { Trailer } \\
\text { (MAV) }\end{array}$} & \multicolumn{2}{l|}{$\begin{array}{l}\text { Truck\Bus } \backslash \\
\text { Tempo }\end{array}$} \\
\cline { 2 - 9 } & $C F_{D}$ & $C F_{T}$ & $C F_{D}$ & $C F_{T}$ & $C F_{D}$ & $C F_{T}$ & $C F_{D}$ & $C F_{T}$ \\
\hline 2014 & 1 & 1.33 & 1 & 1.26 & 1.52 & 1.2 & 1.52 & 1.2 \\
\hline 2015 & 1 & 1.33 & 1 & 1.26 & 1.52 & 1.2 & 1.52 & 1.2 \\
\hline 2027 & 1 & 1.33 & 1 & 1.26 & 1.52 & 1.2 & 1.52 & 1.2 \\
\hline
\end{tabular}

Distance-Related and Time-Related Vehicle Operation Costs are calculated by referring the economic cost data available from Table VOC CARS 26 in Annex D (IRC SP:30- 2009), for uncongested conditions and the WPI data in India is maintained and published by the economic advisory board, Ministry of Commerce and Industry, Government of India (Year 2014). Compare the WPI of Year 2009 and Year 2014, the WPI of year 2014 more than $27 \%$.

\begin{tabular}{|l|l|}
\hline Distance-related VOC costs & Rs/Km \\
\hline Fuel Cost & 1.36 \\
\hline Spare Parts & 0.16 \\
\hline Maintenance Cost & 0.09 \\
\hline Tyre Cost & 0.18 \\
\hline Engine Oil & 0.14 \\
\hline Other Oil & 0.04 \\
\hline Grease & 0.013 \\
\hline Total & $\mathbf{1 . 9 8}$ \\
\hline
\end{tabular}

\begin{tabular}{|l|l|}
\hline Time-Related economic costs & Rs/Km \\
\hline Fixed cost & 1.08 \\
\hline Depreciation Cost & 0.11 \\
\hline Total & $\mathbf{1 . 1 9}$ \\
\hline
\end{tabular}

Distance-Related Vehicle Operation Cost for congested conditions $=$ VOC for uncongested condition $\times \mathrm{CF}_{\mathrm{D}}=1.98 \mathrm{x}$ $1=1.98$. Time-Related Vehicle Operation Cost for congested condition $=\mathrm{VOC}$ for uncongested condition $\mathrm{x}$ $\mathrm{CF}_{\mathrm{T}}=1.19 \times 1.33=\mathbf{1 . 5 8}$ Total of Distance-Related and Time-Related VOC per Kilometer is $=1.98+1.58=$ 3.56The Vehicle Operating cost (case I) for Two Wheeler $=$ Total of Distance-Related and Time-Related VOC per Kilometer $\mathrm{x}$ Vehicles/day $\mathrm{x} 365 \mathrm{x}$ length of road in $\mathrm{Km}=$ $3.56 \times 49585 \times 365 \times 1.4=902$ Laces.

Table-8.1: Total Vehicle operating cost for Case I

\begin{tabular}{|l|l|l|l|l|}
\hline Year & $\begin{array}{l}\text { Motor } \\
\text { Cycle }\end{array}$ & Car/ jeep & Auto & LCV \\
\hline 2014 & 90203048 & 22950481 & 17931005 & 3547264 \\
\hline 2015 & 98321322 & 25016025 & 19544795 & 3866518 \\
\hline 2016 & 107170242 & 27267467 & 21303827 & 4214505 \\
\hline 2017 & 116815563 & 29721539 & 23221171 & 4593810 \\
\hline 2027 & 276544922 & 70361692 & 54972958 & 10875221 \\
\hline
\end{tabular}

Table-8.2: Total Vehicle operating cost for Case I

\begin{tabular}{|l|l|l|l|l|}
\hline Year & $\begin{array}{l}\text { Bus/ } \\
\text { Truck }\end{array}$ & Tractor & MAV & $\begin{array}{l}\text { TOTAL } \\
\text { VOC (Rs) }\end{array}$ \\
\hline 2014 & 4582627 & 156800 & 663068 & 140034296 \\
\hline 2015 & 4995064 & 170912 & 722744 & 152637383 \\
\hline 2016 & 5444619 & 186294 & 787791 & 166374748 \\
\hline 2017 & 5934635 & 203061 & 858692 & 181348475 \\
\hline 2027 & 14049440 & 480719 & 2032838 & 429317793 \\
\hline
\end{tabular}

Table-9: Cost Saving in Vehicle Operation in Vishrambagh Junction

\begin{tabular}{|l|l|l|l|l|l|}
\hline Year & $\begin{array}{l}\text { TOTAL VOC (Rs) } \\
\text { Case I (A) }\end{array}$ & $\begin{array}{l}\text { TOTAL VOC (Rs) } \\
\text { Case II (B) }\end{array}$ & $\begin{array}{l}\text { TOTAL VOC } \\
\text { (Rs) Flyover Case } \\
\text { III (C) }\end{array}$ & $\begin{array}{l}\text { TOTAL VOC } \\
\text { (Rs) Underpass } \\
\text { Case III (D) }\end{array}$ & $\begin{array}{l}\text { Cost Saving } \\
\text { in VOC/yr } \\
\text { (Rs) } \\
\text { (A+B+C+D) }\end{array}$ \\
\hline 2019 & 215460123 & 65283244 & 109222126 & 6257892 & 34696861 \\
\hline 2020 & 234851534 & 72220459 & 120361445 & 6848675 & 35420955 \\
\hline 2027 & 429317793 & 147507683 & 220025430 & 13935980 & 47848700 \\
\hline 2030 & 555978992 & 191026727 & 284939313 & 18047498 & 61965454 \\
\hline
\end{tabular}

\subsection{Cost Saving in Accident}

According to reference paper "Social Cost of Road traffic crashes in India" and Evaluation of Road Accident cost by TCS in IRC SP: 30-2009.
The accident cost increases by $5 \%$ per year, it is kept in mind for calculating the future accident cost. In Vishrambagh Junction, no accident Rate pattern is available. So, the Average no. of accident increases by 1 no. per 3 year (e.g. in year 2014 to 2016 , the average accident is 3 . The average accident is 4 for year 2017 to 2019) and the No. of people die is 1 per 3 year. (E.g. in year 2014 to 2016, the 
average No. of people die is 1 . The average No. of people die is 2 for year 2017 to 2019)

Average No. of Accident $=3$ (Serious Accident), Total Accident Cost $=$ Accident Cost + Vehicle Damage Cost .
According to Accident data and Accident Cost, the total Accident cost in 2014 is $=\{$ (No. of Accident $\mathrm{x}$ Accident Cost $)+($ No. of Vehicle Damage $x$ Vehicle Damage Cost $)\}=\{(3 \times 498181)+(3 \times[42227+8414])\}=16.47$ Lac.

Table-10.1:Accident Cost Saving (Rs) from Signal free Vishrambagh Junction

\begin{tabular}{|c|c|c|c|c|c|c|c|c|}
\hline Year & \multicolumn{2}{|c|}{ Cost of Serious Accident } & \multicolumn{2}{|c|}{ Cost of Fatal Accident } & \multicolumn{2}{|c|}{ Avg Accident / year } & \multirow{2}{*}{$\begin{array}{l}\text { No. of } \\
\text { people } \\
\text { die }\end{array}$} & \multirow{2}{*}{$\begin{array}{l}\text { Total } \\
\text { Accident } \\
\text { Cost saving } \\
\text { per year }\end{array}$} \\
\hline & $\begin{array}{l}\text { Accident } \\
\text { Cost }\end{array}$ & $\begin{array}{l}\text { Vehicle } \\
\text { Damage Cost }\end{array}$ & $\begin{array}{l}\text { Accident } \\
\text { Cost }\end{array}$ & $\begin{array}{l}\text { Vehicle } \\
\text { Damage Cost }\end{array}$ & $\begin{array}{l}\text { Serious } \\
\text { Accident }\end{array}$ & $\begin{array}{l}\text { Fatal } \\
\text { Accident }\end{array}$ & & \\
\hline 2019 & 633099 & 53663 & 1396652 & 127017 & 2 & 2 & 2 & 4420862 \\
\hline 2020 & 664184 & 56298 & & & 5 & & 0 & 3602410 \\
\hline 2021 & 696795 & 59062.04 & & & 5 & & 0 & 3779285 \\
\hline 2027 & 928981 & 78742.6 & & & 7 & & 0 & 7054068 \\
\hline
\end{tabular}

\subsection{Revenue Obtained from Advertisement}

In benefit calculation the next Value is added that is the Revenue coming from Advertisement. The Municipal Corporation can apply charges on the advertisements located on the flyover and underpass and generate money from it. The Charges like permission fee, license fee and tax on advertisement decided by Municipal Commissioner or the Municipal Corporation publish the tender notice for Advertising.

Advertisement Cost per year $=$ Type and size of advertisement $\mathrm{x}$ (Permission fee + License Fee + Tax + Land utilization Charges). Land Utilization charges are considered only for flex or banner. Assume that, the advertisement rates increases by $10 \%$ per 5 year.

Total Revenue $=($ Revenue from Advertisement $)+($ Revenue from land utilization $)=($ Size of hording $\mathrm{x}$ No. of hordings $\mathrm{x}$ charges/ sq. ft. / year $)+($ area of land used per hording $\mathrm{x}$ No. of hordings on ground $\mathrm{x}$ charges/ sq. ft. / year $)=(120 \mathrm{x}$ $30 \times 170)+(15 \times 20 \times 1870)=1173000$.

Total Revenue Coming from Advertisement in year 2014 is = Advertisement on hoardings/post/kiosk/Structure + Advertisement hoarding on Street light + Posters + Advertisement flex banner on outer side of flyover parapet wall + Advertisement flex cross over the flyover $=1173000+$ $285600+12000+499200+332800=\mathbf{2 3 0 2 6 0 0}$ Rs.

Table-11: Total Revenue from Advertisement per year

\begin{tabular}{|l|l|}
\hline Year & Total Revenue From Advertisement \\
\hline 2019 & 2532860 \\
\hline 2020 & 2786146 \\
\hline 2027 & 3064761 \\
\hline 2030 & 3371237 \\
\hline
\end{tabular}

\subsection{Travel Time Saving}

Generally, savings in travel time are enjoyed by bus passengers, car passenger and two-wheeler riders. In travel time saving, time saving for passenger and saving the commodity holding time. In the case of commodities, lesser travel time signifies smaller inventory cost. Speedier travel means that for transporting the same quantity of goods in a certain period, lesser number of commercial vehicles can be used. Speedier travel leads to reduction in the fixed charges per $\mathrm{km}$ which every operator has to pay. Quicker travel also results in time savings to the vehicle crew. The savings in travel time are an important component of the benefits from highway improvements. The Average income of population in Sangli-Miraj-Kupwad area is approximately 30000Rs/Month that means 0.012 Rs / Second/ person. Now, to pass the distance from Jalbhavan-Sangli to Walchand College, Sangli require 238 second according to survey (168 sec for traveling and $70 \mathrm{sec}$ for stopping at signal). Total Cost of travel time saving (Rs/day) $=($ Total No. of Person in Vehicles $x$ Travel Time Saving (Sec) $x$ Cost/Sec per passenger)

Motor Cycle: Peak hour Cost of travel time saving (Rs/day) $=((7224 \times 2) \times 154 \times 0.012)=26700$.

Total Cost of travel time saving (Rs/day) $=\sum$ (Cost of travel time Saving $(\mathrm{Rs}))=147698$.

Commodity Cost saving $=($ Total No. of Vehicles $\mathrm{x}$ Travel Time Saving ( $\mathrm{Sec}) \mathrm{x}$ Commodity holding cost (Rs/sec) $\mathrm{x}$ Total commodity holding cost saving (Rs/day) $=\sum$ (Total commodity holding cost saving (Rs) $=528$.

Total Cost saving in travel (Rs/day) $=$ Total Cost of travel time saving (Rs/day) + Total Commodity holding cost saving $($ Rs/day $)=147698+528=148226$ Rs/day.

The traffic density increases $9 \%$ per year. Assume that, the Average income of Sangli-Miraj-Kupwad Area increases by approximately $3 \%$ per year. The WPI increases $8.5 \%$ per year (approximately) on the basis of study of WPI from 2009 to 2013.

Total Cost of travel time saving (Rs/day) for yr $2020=$ Total Cost of travel time saving (Rs/day) for year $2019 \times 1.09 \times$ $1.03=264388 \times 1.09 \times 1.03=296829$.

Total Commodity holding cost saving (Rs/day) for yr 2020 $=$ Total Commodity holding cost saving (Rs/day) for $\mathrm{yr}$ $2019 \times 1.09 \times 1.085=1221 \times 1.09 \times 1.085=1444$. 
Total Cost saving in travel time (Rs/day) $=$ Total Cost of travel time saving (Rs/day) for yr $2020+$ Total Commodity holding cost saving (Rs/day) for yr $2020=296829+1444=$ 298273.
Total Cost saving in travel time $(\mathrm{Rs} / \mathrm{Year})=$ Total Cost saving in travel time (Rs/day) x $365=298273 \times 365=$ 108869992.

Table-12: Total travel time cost saving

\begin{tabular}{|l|l|l|l|l|l|}
\hline Year & $\begin{array}{l}\text { Total Cost of travel } \\
\text { time saving (Rs/day) }\end{array}$ & $\begin{array}{l}\text { Total Commodity } \\
\text { holding cost saving } \\
\text { (Rs/day) }\end{array}$ & $\begin{array}{l}\text { Total Cost saving in } \\
\text { travel time (Rs/day) }\end{array}$ & Day & $\begin{array}{l}\text { Total Cost saving } \\
\text { in travel time } \\
(\text { Rs/Yr) }\end{array}$ \\
\hline 2014 & 148226 & 528 & 148226 & 365 & 52400860 \\
\hline 2019 & 264388 & 1221 & 265610 & 365 & 96947770 \\
\hline 2020 & 296829 & 1444 & 298273 & 365 & 108869992 \\
\hline 2027 & 667348 & 4674 & 672023 & 365 & 245288565 \\
\hline 2029 & 841163 & 6538 & 847701 & 365 & 309411092 \\
\hline 2030 & 944373 & 7732 & 952106 & 365 & 347518906 \\
\hline
\end{tabular}

Table-13.1: Total Benefit from Signal Free Vishrambagh Junction

\begin{tabular}{|l|l|l|l|}
\hline Year & $\begin{array}{l}\text { Vehicle } \\
\text { operating } \\
\text { cost saving } \\
\text { (VOC) in Rs }\end{array}$ & $\begin{array}{l}\text { Accident } \\
\text { Cost } \\
\text { Saving } \\
\text { (Rs) }\end{array}$ & $\begin{array}{l}\text { Revenue from } \\
\text { Advertisement } \\
\text { (Rs) }\end{array}$ \\
\hline 2019 & 34696861 & 4420862 & 2532860 \\
\hline 2020 & 35420955 & 3602410 & 2786146 \\
\hline 2026 & 43897890 & 6723920 & 3064761 \\
\hline $\mathbf{2 0 2 7}$ & 47848700 & 7054068 & 3064761 \\
\hline 2028 & 52155083 & 13842101 & 3064761 \\
\hline 2029 & 56849041 & 8872888 & 3064761 \\
\hline
\end{tabular}

Table-13.2: Total Benefit from Signal Free Vishrambagh

\begin{tabular}{|l|l|l|l|}
\hline Year & $\begin{array}{l}\text { Travel Time } \\
\text { Saving (Rs) }\end{array}$ & $\begin{array}{l}\text { Total } \\
\text { Benefit } \\
(\text { Rs) }\end{array}$ & $\begin{array}{l}\text { Cumulative } \\
\text { Benefit }\end{array}$ \\
\hline 2019 & 96947770 & 138598353 & 138598353 \\
\hline 2020 & 108869992 & 150679503 & 289277856 \\
\hline 2026 & 218403911 & 272090482 & 1585347674 \\
\hline $\mathbf{2 0 2 7}$ & 245288565 & 303256094 & $\mathbf{1 8 8 8 6 0 3 7 6 8}$ \\
\hline 2028 & 275487766 & 344549711 & 2233153479 \\
\hline 2029 & 309411092 & 378197782 & 2611351261 \\
\hline
\end{tabular}

Table-14: Benefit-Cost ratio for Signal Free Vishrambagh

\begin{tabular}{|l|l|l|l|}
\hline Year & $\begin{array}{l}\text { Cost (Rs) } \\
\text { \{ Cost of } \\
\text { Construction } \\
+ \\
\text { Maintenance } \\
\text { Cost }\end{array}$ & $\begin{array}{l}\text { Benefits (Rs) } \\
\text { \{VOC saving + } \\
\text { Accident Cost } \\
\text { saving + } \\
\text { Revenue from } \\
\text { Advertisement + } \\
\text { Travel Time } \\
\text { Saving (Rs) }\end{array}$ & $\begin{array}{l}\text { Benefit/Co } \\
\text { st } \\
\text { Ratio }\end{array}$ \\
\hline 2019 & 1605100000 & 138598353 & 0.086 \\
\hline 2020 & 1605100000 & 289277856 & 0.18 \\
\hline 2021 & 1605100000 & 455086488 & 0.28 \\
\hline 2025 & 1605100000 & 1313257192 & 0.82 \\
\hline 2026 & 1605100000 & 1585347674 & 0.99 \\
\hline $\mathbf{2 0 2 7}$ & $\mathbf{1 6 0 5 1 0 0 0 0 0}$ & $\mathbf{1 8 8 8 6 0 3 7 6 8}$ & $\mathbf{1 . 1 8}$ \\
\hline
\end{tabular}

\section{CONCLUSION}

1) In junction improvement, it is feasible to provide flyover, underpass and the available area permits its construction.

2) According to Benefit-Cost ratio analysis, the cost forSignal (Congestion) Free Vishrambagh junction is recovered within 9 years

\section{REFERENCES}

[1] James M. Witkowski, "Benefit analysis for urban grade separated interchanges" Associate Member, ASCE.

[2] Stephen R. Alderson and Yorgos J. Stephanedes, "Transportation corridor strategies and land use"M. ASCE.

[3] Samir A. Ahmed, "Urban freeway traffic management technology" M. ASCE.

[4] IRC: 92-1985Guideline for the design of interchanges in urban areas.

[5] IRC: 5- 1998Standard specifications and code of practice for road bridges (Section I).

[6] Transportation research board, National research council, "Highway Capacity Manual 2000

\section{BIOGRAPHIES}

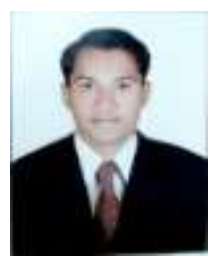

Sanjay Shivaji More, Assistant Professor, Civil Engineering Department, Bhrarati Vidyapeeth's College of Engineering, Lavale, Pune.

Vishal Dhondiram Sabale, Assistant Professor, Civil Engineering Department, Bhrarati Vidyapeeth's College of Engineering, Lavale, Pune. 